\title{
Wenche Vagle
}

Forsker ved Instituttt for lcererutdanning og skoleutvikling, Universitetet i Oslo

Jørgen Frost (red.):

Språk- og lese-veiledning - i teori og praksis

\section{Bokanmeldelse}

"Pakker" er populære i disse finanskrisetider. Jørgen Frost og det øvrige forfatterteamet har med denne boka levert en "pakke" til avhjelping av det noen framstiller som en "lesekrise" i norsk skole. Historien om hvordan denne "krisa" er blitt avdekket og bekreftet gjennom en rekke internasjonale undersøkelser, er velkjent. Det er også de skolepolitiske tiltakene i form av nasjonale prøver og et nytt læreplanverk, Kunnskapsløftet, med vekt på grunnleggende ferdigheter i alle fag. At én av skolens viktigste oppgaver er å gi god leseopplæring, hersker det ingen uenighet om. Men hvordan man skal få alle elever, uansett evner og bakgrunn, til å utvikle sine leseferdigheter optimalt, se det er spørsmålet.

Sammen med sitt dansk-norske forfatterteam presenterer Jørgen Frost et forslag til hvordan skolene, skoleeierne og lærerne bør gripe saken an. For, som det står i bokas vaskeseddel, "situasjonen krever ikke bare kunnskaper hos lærerne, men også samordning og god ledelse - hele skolen må fungere godt". Forslaget er å la en "språk- og leseveileder” få særskilt ansvar for å utvikle, planlegge og koordinere skolens leseopplæring. Ideen er hentet fra Danmark, der en slik ordning er gjennomført ved alle landets skoler. Flere av bokas kapitler formidler erfaringer fra Danmark sett fra ulike ståsteder.

Bokas prosjekt er å presentere teori, forskning, erfaring og konkrete redskaper som denne (nye) språk- og leseveileder-funksjonen kan bygge på. I tillegg inneholder boka et vell av didaktiske tips og opplegg som alle som arbeider med språkstimulering og skriftspråkopplæring i skolen og førskolen, kan ha stor nytte av. Boka er altså både en forskningsbasert teoribok og en håndbok som kan benyttes i planleggingen og gjennomføringen av kommunens eller skolens språk- og leseopplæring. I tråd med dette er bokas målgruppe sammensatt. For, som det påpekes i innledningen, det er langt ifra den enkelte lærer alene som har ansvar for å kvalitetssikre leseopplæringen. Dette må gjøres i et team der skoleledelsen og skoleeieren er involvert sammen med lærere, spesiallærere, PPT og eventuelt den spesielt utpekte (og utdannede) "språk- og leseveilederen”.

Trenger vi nok en bok om utvikling av lesing og andre språklige ferdigheter i skolen og førskolen? På 2000-tallet har vi sett en flom av nye bøker om språkstimulering generelt og om lesing og skriving spesielt - de fleste rettet mot forskere, lærere og lærerstudenter. De første bøkene kom allerede på 90-tallet, ansporet av den nye given i amerikansk og internasjonal forskning på området (se for eksempel Santa og Engen 1993, Frost 1999). Men den store strømmen har kommet utover 2000-tallet i kjølvannet av de internasjonale undersøkelsene 
og Kunnskapsløftet (se for eksempel Bjorvand og Tønnessen red. 2002, Kulbrandstad 2003, Learning Media 2003, Frost 2003, Hekneby 2003, Trageton 2003, Salen 2003, Hagtvet 2004, Maagerø og Tønnessen red. 2006, Bråten red. 2007, Roe 2008). ${ }^{1}$ Med litt ulik vektlegging behandler disse bøkene leseteori, lesedidaktikk, tekstteori og de forskjellige tradisjonene innen leseforskning. De beskriver faser i lese- og skriveutvikling, og de er tydelige på at erobringen av lese- og skrivekompetanse (også kalt "literacy" eller skriftkyndighet) er en integrert prosess som bygger på barnets talespråkkompetanse, noe opplæringen både må ta hensyn til og utnytte. Bøkene tar opp kartlegging av leseferdighet, vurdering av lesekompetanse, utvikling av gode lesestrategier og metakognitiv bevissthet og dessuten praktiske metoder i skriftspråkopplæringen. En god del plass er viet emner som KL06 legger vekt på, som lesing i alle fag og lesing av multimodale tekster. Innføringer i temaer som lese- og skrivevansker og de minoritetsspråkliges spesielle utfordringer finner man også i disse bøkene, samt noe om programvare og datamaskin-støttet leseopplæring.

Alt dette får man også i den nye boka som Frost har redigert - og man får det i framstillinger som er forskningsbasert, oppdatert og didaktisert. Dessuten handler ett av kapitlene om hvordan man kan måle effekt av leseopplæringen, mens to kapitler er viet matematikkopplæringen - ett handler om faget generelt og det andre om forskjeller og fellestrekk mellom språk- og matematikkvansker (matematikkapitlene er inkludert for at språk- og leseveilederen skal få innblikk i den tradisjonen matematikkfaget står i til forskjell fra den norskfaglige tradisjonen). Gjennomgående legges det stor vekt på differensieringsaspektet og på samordningen fra barnehage til de høyeste årstrinn. Et konstruktivistisk læringssyn gjennomsyrer framstillingene, og lærdommen om at det er bedre å forebygge enn å reparere, går som et mantra gjennom hele boka.

Men det mest originale bidraget boka kommer med, er det overgripende systemperspektivet og den håndgripelige konkretiseringen av alle de ulike funksjonene og rollene som omfattes av dette perspektivet. Dette skjer i de sju første kapitlene, som er samlet under tittelen "Generelle forhold for språk- og leseveiledning” og utgjør den første av de to hoveddelene som boka er inndelt $\mathrm{i}$. Brukervennligheten i framstillingen av dette stoffet er stor. I kapittel 1 defineres språk- og leseveilederrollen ved hjelp av en liste over rolleinnehaverens funksjoner ("Språk- og leseveilederen skal ..." - fra punkt 1 til punkt 9 med grundige utdypninger). Her finner vi også et forslag til en konkret plan over oppgavenes fordeling fra årstrinn 1 til 10. I kapitlene som følger, leverer forfatterne velvillig ut forslag til detaljerte "gjørelister”, sjekklister, dagsorden-punkter og samtaleskjemaer til ulike aktiviteter (for eksempel veiledningssamtaler og leseplanleggingsmøter). Underveis får vi innføringer i språk- og leseveilederens

\footnotetext{
${ }^{1}$ Denne lista er konsentrert om bøker som primært handler om lesing. Omtrent like store, om ikke større, menger litteratur har kommet ut om skriving, tekstkompetanse og generell norskdidaktikk. Det er også utgitt bøker om muntlige ferdigheter, om lese- og skrivevansker og om de spesielle utfordringene leseopplæring for minoritetsspråklige elever byr på.
} 
roller som innovatør og som veileder og dessuten en dansk rektors erfaringer fra en 10 år lang prosess med språk- og leseveiledning - fra de opprinnelige målformuleringene for prosessen til den tentative arbeidsbeskrivelsen for språkog leseveilederrollen som gradvis har vokst fram ved hennes skole. Det ytes også hjelp til foreldre i familier med "vondt i leksene".

Del 2 av boka består av 13 kapitler under tittelen "Didaktiske nøkkeltemaer”. Her innvies leseren i forskningsfronten innen norsk og internasjonal lese- og skriveforskning. Resultatene fra de mange forsknings- og utviklingsprosjektene som berøres, formidles gjennomgående fra et didaktisk perspektiv. Vi finner den samme grundigheten og pluraliteten i aspekter og perspektiver i denne delen av boka som i den første delen. Graden av konkretisering er høy også her. For spesifiserte utviklings- eller alderstrinn finner vi forslag til ulike aktiviteter med utbygde aktivitetsbeskrivelser, læringsmål og didaktiske framgangsmåter. Vi finner konkrete stikkord og sjekklister for arbeid med ulike deler av lesekompetansen. Vi finner lister med konkrete kjennetegn på god lesekompetanse. Vi finner strukturerte verktøy for kartlegging av lese/skrivekompetanse, og spørreskjemaer for kartlegging av holdninger til lesing og skriving. Vi finner sjekkliste over intensiveringstiltak og didaktisk oppfølging i ulike situasjoner. Vi finner eksempler på konkrete handlingsplaner for lesing i ulike fag. Vi finner utdypede storyline-opplegg med læringsmål og erfaringer fra gjennomføringer og dessuten detaljerte beskrivelser av lesekurs i alle sine faser. De pedagogiske oppleggene er gjennomgående presentert med konkrete verktøy som skjemaer og arbeidsark. Vi får også tips om digitale lære- og hjelpemidler, samt læringsressurser på Internett.

Som vi har sett, utgjør boka en svært så innholdsrik pakke, som man kan pakke ut lag for lag og slik få belyst stadig nye - og dypereliggende - aspekter ved temaet slik de trer fram fra stadig nye perspektiver. Eller man kan velge forholdsvis fritt hvilke småpakker av noen kapitler man til enhver tid ønsker å åpne ut ifra foreliggende kunnskapsbehov.

Som det går fram av det ovenstående, er framstillingene i boka preget både av bredde og dybde. Dette hadde neppe vært mulig uten det store forfatterteamet, som teller hele 19 personer. Her finnes mange ulike fagkompetanser og erfaringsbakgrunner representert. Vi finner forskere, lærerutdannere, lærere, lektorer og pedagoger (deriblant én som beskjeftiger seg med ledelse, innovasjon og endringsprosesser i skolen). Vi finner spesialpedagoger (med innretning logopedi og språk-, lese- og skrivevansker), og dessuten leseveiledere utdannet i Danmark. Også andre skoleroller er inkludert - som rektor, skolebibliotekar og PP-tjenesten (inkludert en skolepsykolog). Vi finner rådgivere, lesekonsulenter, IT-konsulenter og en mangeårig lærer og lærerbokforfatter med særskilt kompetanse på opplæring for minoritetsspråklige elever.

Brukervennligheten preger også de mer tekniske sidene av boka. Boka er oversiktlig organisert og har en hjelpsom innledning, som motiverer utvalget både av fagstoff og fagkompetanser hos forfatterne. Dekkende kapittelover- 
skrifter, ansporende ingresser, løpende topptekster og et strukturert stikkordregister gjør boka lett å finne fram i. Dette støttes av en leservennlig typografi med gode fonter, fine kontraster i fontvalg og -størrelse, og dessuten rikelig med luft. Det nostalgiske omslaget, der boktittel og redaktørnavn står skrevet med hvitt kritt på grønn tavle, vil forhåpentlig vekke gode minner hos potensielle lesere og kjøpere. Rikholdige litteraturlister gir gagnlig støtte for dem som ønsker å sette seg (enda) grundigere inn i bokas ulike temaer. Halvparten av kapitlene er forfattet på dansk og oversatt til norsk. Til tross for dette og størrelsen på forfatterteamet løper teksten jevnt over i grei akademisk prosa, som kaller på lite oppmerksomhet på egne vegne. Unntakene er stort sett positive - i form av en og annen interessevekkende metafor eller fabelliknende historie. På ett kapittel nær har forfattere, redaktør og oversetter evnet å skape en stilistisk og retorisk helhet.

Skoler og kommuner over det ganske land er opptatt av å bedre leseresultatene sine. En forutsetning for å lykkes er at alle de involverte kjenner, ikke bare sine egne roller og krav til innsats, men også alle de andres. Her kan boka være til hjelp ved at den tilbyr innføringer i alle de ulike rollene og beskriver det optimale samspillet mellom dem. Boka holder ganske visst fram et ideal, men et ideal forstått som prosess - noe å styre etter og å strekke seg mot. Boka er faktisk noe såpass sjeldent som en aksjonsbok i og med at den kan leses som en oppfordring til norske kommuner og skoler. Da gjenstår det bare å se hva de svarer.

\section{Referanser}

Bjorvand, Agnes Margrethe og Elise Seip Tønnessen (red). 2002. Den andre leseopplcringa.

Utvikling av lesekompetanse hos barn og unge. Oslo: Universitetsforlaget.

Bråten, Ivar (red.). 2007. Leseforståelse. Lesing i kunnskapssamfunnet - teori og praksis.

Oslo: Cappelen Akademisk Forlag.

Frost, Jørgen. 1999. Lesepraksis - på teoretisk grunnlag. Oslo: Cappelen Akademisk Forlag.

Frost, Jørgen. 2003. Prinsipper for god leseopplcering. Oslo: Cappelen Akademisk Forlag.

Hagtvet, Bente. 2004. Språkstimulering. Tale og skrift i førskolealderen. Oslo: Cappelen

Akademisk Forlag.

Hekneby, Greta. 2003. Skrive - lese - skrive. Begynneropplcering i norsk. Oslo:

Universitetsforlaget.

Kulbrandstad, Lise Iversen. 2003. Lesing i utvikling. Teoretiske og didaktiske perspektiver.

Bergen: Fagbokforlaget/LNU.

Learning Media. 2003. A lese for livet. Barn lerer å lese. Oslo: Cappelen Akademisk Forlag.

Maagerø, Eva og Elise Seip Tønnessen (red.). 2006. Å lese i alle fag. Oslo:

Universitetsforlaget.

Roe, Astrid. 2008. Lesedidaktikk - etter den første leseopplæringen. Oslo:

Universitetsforlaget.

Salen, Gerd B. 2003. Lese- og skriveopplcering i grunnskolen. Kvalitetssikring av ferdigheter.

Oslo: Universitetsforlaget.

Santa, C.M. \& Liv Engen. 1993. A lcere å lese. Bryne: Stiftelsen Dysleksiforskning

Trageton, A. 2003. Å skrive seg til lesing. IKT i småskolen. Oslo: Universitetsforlaget. 